\title{
Consumption and awareness of students about nonsteroidal anti-inflammatory drugs
}

\author{
Ewelina Wawryk-Gawda*, Patrycja Chylinska-Wrzos, \\ MARTA Lis-SOCHOCKA, BARBARA JODLOWSKA-JEDRYCH
}

Chair and Department of Histology and Embryology with Experimental Cytology Unit, Medical University of Lublin, 20-080 Lublin, 11 Radziwiłłowska, Poland

\begin{tabular}{l}
\hline ARTICLE INFO \\
\hline Received 5 September 2014 \\
Accepted 6 November 2014 \\
\hline
\end{tabular}

\section{Keywords:}

NSAIDs,

pain,

inflammation,

fever,

adverse effects.

\begin{abstract}
Nonsteroidal anti-inflammatory drugs (NSAIDs) are used by millions of people worldwide to neutralize pain that is of different origin, as well as to treat fever and inflammation. However, NSAIDs misuse/overuse can induce many adverse effects and some potentially serious complications. The aim of the our study was to ascertain young people's knowledge about non-steroidal anti-inflammatory drugs. The research tool was a questionnaire. This study was carried out among students of the Medical University in Lublin, and it involved 236 persons of an average age of 20 years. The questions were intended to assess the frequency of NSAIDs use and the general knowledge that is held with respect to them. The results of this work show that more than $77 \%$ of the respondents confirmed that they use NSAIDs. Our results revealed no statistical correlation between the place of living or origin and the use of this drug. Hence, it can be said that while young adults quite often use NSAIDs, their knowledge about the dangers associated with the use of NSAIDs is low. Therefore, it is necessary to more intensively disseminate knowledge on the potential adverse effects of NSAID utilization.
\end{abstract}

\section{INTRODUCTION}

Nonsteroidal anti-inflammatory drugs (NSAIDs) are used by millions of people worldwide to neutralize pain, fever and inflammation. The easy access to NSAIDs and the universality of utilization amongst people worldwide brings about the notion that NSAIDs are without adverse effects. Due to this universality of thinking, diagnosing and treating the patient displaying acute or chronic complications after NSAID employment has become a serious problem in today's medicine. One of most common side effects of NSAID overconsumption is gastrointestinal tract injury. This is signaled by abdominal pain, heartburn, nausea, as well as dyspepsia, and results in gastroduodenal lesions, bleeding, and gastroduodenal mucosa damage $[2,12]$. Beyond this, NSAID misuse can lead to very serious hematological complications such as aplastic and hemolytic anemia, or thrombocytopenia. It should, as well, be noted that systemic side effects can be expressed. Among these are headaches and dizziness, insomnia, shortness of breath and palpitations

\footnotetext{
Corresponding author

e-mail: ewelina.wawryk@wp.pl,

tel.: 48508191144
}

$[3,10]$. Other side effects include skin reactions such as nettle-rash, erythema, phototoxic and photoallergic reactions, especially in people exposed to ultraviolet radiation [2]. Hence, patients experiencing the complications caused by NSAIDs frequently require costly and prolonged treatment [13]. Of note too, is the linkage of psychological problems to the abuse/consumption of NSAIDS [6].

The increasing chronic and over-consumption of NSAIDs by young people and the resulting hospitalizations induced us to attempt an analysis of degree of awareness held by students with regard to the adverse effects of nonsteroidal anti-inflammatory drug over use. Although, medical students should probably have a high knowledge of the action and indications for the use of NSAIDs and should know the side effects of these drugs, in our work, we assessed the frequency of use of such medicines by students, as well as the general knowledge they held with respect to NSAIDs. Among the information we gathered in this endeavour were place of purchase, and the type and purpose of the application of these drugs. Moreover, we attempted a correlation of place of origin and NSAIDs use. 


\section{MATERIAL AND METHODS}

An anonymous questionnaire form was the research tool, and the survey was conducted in 2013, amongst randomly chosen students of the Medical University in Lublin. The questionnaire form consisted of 23 questions concerning the taking of, and the knowledge about non-steroidal antiinflammatory drugs and paracetamol. Students were asked, among other issues, about their origin (city, village), type of NSAID taken, the frequency of self-administration, form of the taken medicine, point of purchase of the product chosen, and for their opinion about current NSAID availability. The collected data were written in the form of tables and graphs and subjected to a statistical analysis. In the analysis, a correlation was also assessed between the place of origin of the respondent and the given reply. Moreover, the relation between studied notions was examined by way of using the $\mathrm{Chi}^{\wedge} 2$ Pearsona Test, and further manipulated through employing statistical estimation by way of the Statistica 10.0 program.

\section{RESULTS}

In total, 236 persons took part in the study, including 164 women and 72 men living temporarily or permanently in various parts of Lublin. Their median age amounted to 20 years old. The youngest participant in the examination was 18 years old, the oldest 28 years old. Of the surveyed individuals, 167 (71\%) lived permanently in Lublin, while the remainder came from various rural municipalities. To the question "Are you taking medicines from the NSAID group?", about $77 \%$ of the respondents answered affirmatively (Table 1). No significance was seen in NSAID use and origins $(0,273853)$.

The respondents were then asked about the frequency of their taking of non-steroidal anti-inflammatory drugs (Table 1). In reply, of those originating from the city environs, a majority (33\% of the examined) admitted that NSAIDs were used several times in the month. With respect to those originating from rural municipalities, a majority $(38 \%)$ stated that NSAIDS are reached for only a few times in the year. However, a statistical analysis did not indicate a significant relationship between the frequency of antiinflammatory drug employment, with the place of origin $\left(\mathrm{p}=0,415388\right.$ in the $\mathrm{Chi}^{\wedge} 2$ Pearsona Test). According to the results of the survey, the majority of individuals take NSAIDs in order to soothe pain, more rarely to counter fever or cold symptoms (Table 2).

From the responses, the most common form employed is that of pills (about $100 \%$ of the respondents). Far fewer take NSAIDs in the form of suppositories, injections and soluble powders (Table 2). The place of purchase of NSAIDs for the majority of respondents is the pharmacy (97\% of respondents). These medicines are also being procured in shops, petrol stations and by way of the Internet (Table 2). NSAIDs are often taken with other substances, and according to the responses we received, about $13.84 \%$ of all respondents do so (Table 2).

The respondents were asked about their knowledge of the medicament, and about the availability of the product

Table 1. Responses to questions about the frequency of NSAIDs use

\begin{tabular}{|c|c|c|c|c|c|c|c|}
\hline Origin & $\begin{array}{c}\text { "Are you taking medicines from } \\
\text { the NSAID group?" }\end{array}$ & \multicolumn{6}{|c|}{ "How often are you taking medicines from the NSAID group?" } \\
\hline Value & yes & once/year & $\begin{array}{c}\text { several times/ } \\
\text { year }\end{array}$ & once/month & $\begin{array}{c}\text { several times/ } \\
\text { month }\end{array}$ & once/week & $\begin{array}{c}\text { several times/ } \\
\text { week }\end{array}$ \\
\hline$\%$ from city & $79.04 \%$ & $6.11 \%$ & $29.01 \%$ & $22.14 \%$ & $32.06 \%$ & $5.34 \%$ & $5.34 \%$ \\
\hline$\%$ from village & $72.46 \%$ & $6.00 \%$ & $38.00 \%$ & $14.00 \%$ & $36.00 \%$ & $6.00 \%$ & $0.00 \%$ \\
\hline$\%$ from the whole & $77.12 \%$ & $6.08 \%$ & $31.49 \%$ & $19.89 \%$ & $33.15 \%$ & $5.52 \%$ & $3.87 \%$ \\
\hline Chi^2 Pearsona & $1,19735, d f=1, p=0,273853$ & \multicolumn{6}{|c|}{$5,00404, d f=5, p=0,415388$} \\
\hline
\end{tabular}

Table 2. Responses to specific questions regarding the use of NSAIDs

\begin{tabular}{|c|c|c|c|c|c|}
\hline Question & Answer & City & Village & Together & $\mathrm{Chi}^{\wedge} 2$ Pearsona \\
\hline \multirow{3}{*}{$\begin{array}{l}\text { "For what purpose are you } \\
\text { taking medicines from the } \\
\text { NSAID group?" }\end{array}$} & Against fever & $50.38 \%$ & $44.00 \%$ & $48.62 \%$ & $0,589962, d f=1, p=0,442434$ \\
\hline & Anti-inflammatory & $19.08 \%$ & $20.00 \%$ & $19.34 \%$ & $0,019468, d f=1, p=0,889033$ \\
\hline & Against cold & $44.96 \%$ & $36.00 \%$ & $42.46 \%$ & $1,18440, d f=1, p=0,276462$ \\
\hline \multirow{4}{*}{$\begin{array}{l}\text { "What pharmaceutical form of } \\
\text { NSAID are you using?" }\end{array}$} & Pills & $98.46 \%$ & $100.00 \%$ & $98.88 \%$ & $0,746853, d f=1, p=0,387474$ \\
\hline & Suppositoria & $0.77 \%$ & $0.00 \%$ & $0.56 \%$ & $0,371317, d f=1, p=0,542287$ \\
\hline & Injections & $1.54 \%$ & $0.00 \%$ & $1.12 \%$ & $0,746853, d f=1, p=0,387474$ \\
\hline & Soluble forms & $4.62 \%$ & $2.08 \%$ & $3.93 \%$ & $0,594916, d f=1, p=0,440525$ \\
\hline \multirow{4}{*}{$\begin{array}{l}\text { "Where do you buy your } \\
\text { NSAIDs?" }\end{array}$} & Pharmacy & $96.15 \%$ & $100.00 \%$ & $97.22 \%$ & $1,97802, d f=1, p=0,159599$ \\
\hline & Shop & $30.77 \%$ & $26.00 \%$ & $29.44 \%$ & $0,395369, d f=1, p=0,529490$ \\
\hline & Petrol station & $5.38 \%$ & $6.00 \%$ & $5.56 \%$ & $0,026063, d f=1, p=0,871746$ \\
\hline & Internet & $4.65 \%$ & $0.00 \%$ & $3.35 \%$ & $2,40624, d f=1, p=0,120853$ \\
\hline \multirow{4}{*}{$\begin{array}{l}\text { "Are you taking NSAIDs } \\
\text { in combination with other } \\
\text { substances?" }\end{array}$} & Yes with Alcohol & $4.94 \%$ & 0 & $4.94 \%$ & \multirow[t]{4}{*}{$11,8367, d f=5, p=0,037095$} \\
\hline & Yes with Other drugs & $1.64 \%$ & $2.20 \%$ & $3.84 \%$ & \\
\hline & Yes with Caffeine & $0.55 \%$ & 0 & $0.55 \%$ & \\
\hline & Yes with Herbs & 0 & $0.55 \%$ & $0.55 \%$ & \\
\hline
\end{tabular}


Table 3. Responses to questions regarding the marketing and use of NSAIDs

\begin{tabular}{|l|c|c|c|c|}
\hline \multicolumn{2}{|c|}{ NSAIDs question } & \multicolumn{3}{c|}{ Percentage of persons which answered "yes" to the presented questions } \\
\cline { 2 - 5 } & City & Village & Together & \multicolumn{1}{c|}{ Chi^2 Pearsona } \\
\hline Do you think that NSAIDs use is safe? & $46.99 \%$ & $45.59 \%$ & $46.58 \%$ & $0,746391, \mathrm{df}=2, \mathrm{p}=0,688531$ \\
\hline Do you know of the adverse effects of NSAIDs use? & $30.30 \%$ & $28.99 \%$ & $29.91 \%$ & $0,040283, \mathrm{df}=1, \mathrm{p}=0,840928$ \\
\hline $\begin{array}{l}\text { Do you think that all medicines from the NSAIDs group should } \\
\text { be sold without a prescription? }\end{array}$ & $43.98 \%$ & $37.68 \%$ & $42.13 \%$ & $5,18183, \mathrm{df}=3, \mathrm{p}=0,158957$ \\
\hline $\begin{array}{l}\text { Do you think that, at present, the existing availability of NSAIDs } \\
\text { is appropriate? }\end{array}$ & $72.29 \%$ & $66.67 \%$ & $70.64 \%$ & $0,91727, \mathrm{df}=2, \mathrm{p}=0,232553$ \\
\hline $\begin{array}{l}\text { Do you think that selling NSAIDs in such places as shops is } \\
\text { appropriate? }\end{array}$ & $57.23 \%$ & $59.42 \%$ & $57.87 \%$ & $0,096003, \mathrm{df}=1, \mathrm{p}=0,756680$ \\
\hline Do you think that NSAIDs are abused? & $36.75 \%$ & $52.17 \%$ & $41.28 \%$ & $4,87760, \mathrm{df}=2, \mathrm{p}=0,087265$ \\
\hline Is it appropriate for the media to market painkillers? & $43.98 \%$ & $44.93 \%$ & $44.26 \%$ & $0,017892, \mathrm{df}=1, \mathrm{p}=0,893592$ \\
\hline
\end{tabular}

within Poland (Table 3). About half stated that they believe NSAIDs are safe to take, but about $70 \%$ had no idea of the adverse effects of the item. In addition, about $40 \%$ think they should be sold without prescription and made generally available, as opposed to being sold only within pharmacies. Moreover, $70 \%$ of the respondents opine that the current marketing is appropriate. However about $30 \%$ think restrictions should be made on their sale. What is more, $41 \%$ feel that NSAID use is abused. The responses had no geographical interconnection.

\section{DISCUSSION}

Although it is recognized that many adverse effects accompany the use of NSAIDs, they constitute one of the most often taken groups of medicines worldwide, and this currently constitutes a serious problem [13]. NSAIDs are prescribed widely for many reasons, among them, as adjunct treatments for rheumatoid diseases (rheumatic arthritis), for neurological reasons (for treatment of back pain), as well as in the treatment of various cancers [3,9]. However, their known painkilling, febrifugal and anti-inflammatory effects ensure that they are often used and repeatedly overused without medical consultation, to relieve headache, menstrual cramps, cold and flu symptoms [3]. The choice of preparation and the dosage is usually based upon knowledge gained from television commercials, newspapers, Internet or the personal recommendations of acquaintances.

Moreover, the assumption is that the given medicine and dosage is completely safe, and the information attached to the package is most often not read (such information must be supplied, usually in the form of an insert, according to law) [3,11]. Furthermore, as evident in our survey, certain individuals link other medicines with NSAID use (80\%), while some have the absurd notion of linking NSAID use with alcohol consumption $(13,84 \%)$.

Our survey was conducted amongst individuals between the ages of 18-28, not burdened with major diseases. They reach for NSAIDs in order to relieve headache, belly pains, and pain associated with menses. Of note, some respondents state that they take these medicines for longer periods of time, and five individuals stated that they have a psychological dependence upon them.

In spite of the common use of NSAIDs among the majority of respondents, only a $30 \%$ are aware of their adverse effects, while, about $50 \%$ of those surveyed, opine that NSAIDs are safe to use, and their application for treatments need not be done via consultation with medical or pharmaceutical experts. Moreover, they see no problem with their advertisement via the media, or their sale in general places such as kiosks or petrol stations. Although about $70 \%$ of the respondents think that the NSAID availability as is currently practiced in Poland is appropriate, and while almost everyone who completed our survey bought these medicines in a pharmacy, about $40 \%$ profess that these drugs are abused.

We can conclude from our survey that the knowledge of young adults about the dangers connected with NSAID use is quite low. The universality of their availability, and their advertisement, as well as the assumed knowledge of affect and side-effect, brings about the false notion that these medicaments are safe for common employment. It is obvious from our results that few individuals observe the early hypersensitivity reaction associated with NSAID use that appears within 24 hours from in-putting the substance. Nor do they realize that sometimes these reactions are quite violent and can lead to internal bleeding, nephritis, pneumonia and meningitis $[8,11]$. Therefore, it is necessary to disseminate knowledge about NSAID use and abuse, as well as their possible side-effects and their appropriate dosages [4]. Parents of small children should in particular, have information supplied about the effect of these medicines, because such small children are especially vulnerable to NSAID side effects [7].

It is our belief that the availability of medicines from the NSAIDs group should be adapted for the needs of the given population, including a quantitative restriction, in order to prevent the numerous suicide attempts brought about through their misuse [6]. Furthermore, it must be recognized that these medicaments are an environmental concern, as they do not decompose and hence, contaminate water supplies [1]. Therefore, users and consultants to their use must understand that they be applied in the lowest effective dose possible and for the shortest time necessary to control symptoms according to the therapeutic objective established. In addition, the prescription should be based on the safety profiles of each of the active ingredients and after excluding diseases which need the causal treatment [5].

\section{CONFLICT OF INTEREST}

The authors declare that they have no conflict of interest. 


\section{REFERENCES}

1. Adamek E. et al: Photodegradation of the selected anti-inflammatory drugs in the aquatic environment. Proceedings of ECOpole 5(1), 147, 2011.

2. Broniarczyk-Dyła G., Urysiak-Czubatka I.: Cutaneous adverse effects of nonsteroidal anti-inflammatory drugs. Post Dermatol Alergol. XXIV, 6, 247, 2007.

3. Gadomski A.: Nonsteroidal anti-inflammatory drugs in the medicine cabinet. Med Rodzinna 2, 37, 2006 [In Polish]

4. Gazarian M., Graudins L.V.: Safe use of NSAIDs in infants and children. Medicine Today 7(11), 71, 2006.

5. Gené E., Calvet X., Morón A., Iglesias M.L.: Recommendations for the use of anti-inflammatory drugs and indications for gastrointestinal protection in emergency departments. Emergencias 21, 295, 2009.

6. Hawton K. et al: Long term effect of reduced pack sizes of paracetamol on poisoning deaths and liver transplant activity in England and Wales: interrupted time series analyses. $B M J 7,346$, 2013:f403. doi: 10.1136/bmj.f403.
7. Hernández- Cortez E.: Non-steroidal Anti-inflammatory Analgesics in Children. Anestesia en México 18(1), 162, 2006.

8. Kowalski M.L. et al: Hypersensitivity to nonsteroidal antiinflammatory drugs (NSAIDs) - classification, diagnosis and management: review of the EAACI/ENDA(\#) and GA2LEN/HANNA*. Allergy 66(7), 818, 2011. doi: 10.1111/j.1398-9995.2011.02557.x.

9. Luo X. et al: Prescription of nonsteroidal anti-inflammatory drugs and muscle relaxants for back pain in the United States. Spine 1,29(23), 2004:E531-E537.

10. Międzybrodzki R.: Kierunki poszukiwań i zastosowanie niesteroidowych leków przeciwzapalnych. Post. Hig. i Med. Dośw. $58,438,2004$.

11. [Reguła J. et al: Stosowanie niesteroidowych leków przeciwzapalnych w Polsce - badanie ankietowe u 38 tysięcy chorych. Gastroenterologia Kliniczna 3(2), 72, 2011.

12. Vonkeman H.E., Van De Laar M.A.: Nonsteroidal anti-inflammatory drugs: adverse effects and their prevention. Semin Arthritis Rheum. 39(4), 294, 2010. doi: 10.1016/j.semarthrit.2008.08.001,

13. Wisłowska M.:Przewlekłe stosowanie NLPZ - zagrożenia, potencjalne powikłania. Med Rodzinna 1, 22, 2004. 